\title{
Panel Data Analysis of Monetary Transmission Mechanism for European Union Countries
}

\author{
Dina CAKMUR YILDIRTAN (Corresponding author) \\ Banking and Insurance College, Capital Market Dept., Marmara University \\ Goztepe Campus, Ziverbey, İstanbul, Turkey \\ Tel: 90-532-276-8922Ｅ-mail: dinacakmur@yahoo.com.tr
}

Selin SARILI

Banking and Insurance, Istanbul Sisli Vocational School

Buyukdere St. No:100, Esentepe-Sisli, Istanbul, Turkey

Tel: 90-533-728-2856_E-mail: selin.sarili@sisli.edu.tr

Received: February 19, 2017 Accepted: March 13, 2017 Published: March 15, 2017

doi: 10.5296/jsss.v4i2.10731 URL: http://doi.org/10.5296/jsss.v4i2.10731

\begin{abstract}
Monetary transmission mechanism is the mechanism which shows in what ways and what extent interaction between the real economy-monetary policy, impacts aggregate demand and production. While transmission channels or mechanisms traditionally classified they divided into three categories; interest rates, Exchange rates and other asset prices.

In this study to test the existence of the European debt crisis by the monetary transmission mechanism, 15 members of European Union country by using annual (2002-2014) data set were included into study. We use panel unit root tests to analyze whether the variables in the model are stationary or not. For the countries included in the study, panel causality tests developed by Granger is applied. Panel Vector Autoregressive Model has been estimated and results of Impulse-Response Analysis and Variance Decomposition have been interpreted.
\end{abstract}

Keywords: Monetarytransmissionmechanism, Panel data analysis, Eurodebtcrisis

\section{Introduction}

The impulses of globalization and recent developments have caused negative effect on monetary transmission channels and decreased the efficiency of monetary policy instruments. 


\section{Macrothink}

Journal of Social Science Studies

ISSN 2329-9150

2017, Vol. 4, No. 2

The uncertainties that experienced in financial markets have made it difficult for Central Banks to achieve their goals, negatively affected monetary transmission mechanism and made it an obligation for central banks to find new policy instruments.

Monetary policies followed by Central Banks went beyond monetary policy instruments upon complication on financial markets and central banks had to develop traditional monetary policy instruments. After the global crises, it has become priority to enable stability not only on prices but also on financial markets.

It is important that central bank manage monetary policy independent from the government, transparency is established and price stability is determined as the main goal in order to have an efficient monetary policy of Central Banks (CB). It is also seen from European Central Bank that the main goal is to enable price stability.

It is very important for the actors in the market for accurate interpretation of the decisions and taking actions that Central Bank has an independent decision mechanism. The difference between targeted inflation and actual inflation is important in terms of expectations in a CB conducting inflation targeting. Undoubtedly, one of the biggest appliers of policies conducted by $\mathrm{CB}$ is the bank.

Banking system is very important in financial markets where fund suppliers and fund demanders meet. Therefore, a decision of CB should have a level that will have an impulse on banking system that affects not only fund demanders but also fund suppliers. This means, CBs may conduct money amount best on markets through the banks channel.

Monetary transmission mechanism shows the channel of influence of monetary policies applied by Central Banks and how long they will be effective. It varies from country to country which transmission channel is more effective on monetary transmission mechanism. A change of monetary policy interest rates shall be effective on exchange rates, asset prices, credits and market expectations. Affecting the producer and consumer behaviors in the following phase, monetary policy decisions shall finally affect the foreign trade and economic growth of the country.

\section{Literature}

It is seen in the literature that many studies have been conducted on monetary transmission mechanism channels.

Exchange rate channel of monetary transmission mechanism in Germany has been analyzed with method VAR for the period Smets and Wouters (1999).

Bernanke and Gertler (1995) have shown how difficult it is to explain the response of economy on monetary shock through interest rate channels in their study and studied on credit channel.

Gerlach and Smets (1995) searched the monetary transmission mechanism for G-7 countries with VAR analysis. They found that over the estimation period of 1979-1993 standardized monetary policy tightening on output and inflation are similar in Canada Germany and USA. The point estimates of the effect on output in France and Italy are smaller but may be absence of a significant exchange rate channel in these countries during the estimation period.

Taylor (1995) stated that interest rate channel is a strong channel in monetary transmission mechanism. According to Taylor, the change on interest rates is effective on prices in general 
and production.

After creating European Monetary Union, Angeloni and Ehrmann (2003), have searched in their study whether monetary transmission mechanism changes or not and countries have a more homogeneous structure due to monetary union. They analyzed transmission channels through banks; interest rate and asset prices channel and concluded that transmission mechanism through banks is more effective.

In 2001, Mishkin analyzed the effect of monetary policy on stock certificates. Sims (1992) made an international comparison of monetary transmission mechanisms for G-7 countries and concluded that interest rate shock quickly decrease industrial production in the short term.

Camarero et al. (2002) analyzed monetary transmission channels through co-integrated structural VAR method for 1986-1998 periods in Spain and concluded that monetary tightening caused a downstream, weak impulse on prices.

De Bondt (2002) analyzed the response of macroeconomic variables against monetary policy shock in a study on Euro Zone. No results were reached on presence of credit channel besides the countries Great Britain and Belgium in the study covering the data of Germany, Italy, France, The Netherlands, Great Britain and Belgium.

Peersman and Smets (2001 )have estimated VAR on Euro area data from 1980 till 1998. They investigated the macro-economic effects of a monetary policy shock in the euro area, especially an unexpected monetary policy tightening in the euro area. A temporary rise in the nominal and real short-term interest rate tends to be followed by a real appreciation of the exchange rate and a temporary fall in output. Prices are weaker and only start to fall significantly below zero several quarters after GDP.

\section{Monetary Transmission Mechanism}

Monetary transmission mechanism aims establishing how monetary policy decisions may affect the economy through different channels. On the other hand, it is possible to describe monetary transmission mechanism as the total demand of monetary policy decisions, impulse process for inflation expectations and inflation ratio (Petursson, 2001: 62). Under this frame, four different monetary transmission channels can be mentioned: These are respectively, interest rate channel, asset prices channel, credit channel and exchange rate channel.

\subsection{Interest Rate Channel}

According to the traditional Keynesian interest rate channel approach, interest rate increases on nominal interest rates arising from politics cause long-term nominal interest rate increases. Therefore, as also described in the expectations hypothesis, arbitragers have to invest in different term debt instruments. When the adaptation on nominal prices is slow, this situation shall reflect on the movement in real interest rate. When the companies find the debt costs high, they shall cut the investment costs. This applies not only to the companies but also to household expenditures.

According to Hicks (1937), interest rate channel lays in the heart of traditional Keynesian IS-LM model. It is at the same time seen in Neo-Keynesian models. In open economies, additional real impulses of increase on short-term interest rates occur through foreign currency channel. 


\section{MInstitute ${ }^{\text {Macrothink }}$}

Journal of Social Science Studies

ISSN 2329-9150

2017, Vol. 4, No. 2

There is a relation defined as Uncovered Interest Parity between nominal interest rates and expected devaluation under the assumption that capital moves freely in international markets and the risk is zero (Dornbusch, 1988):

$$
t=t^{*}+x
$$

In the equation, $\dot{i}$ shows domestic interest rate ratios, $i^{*}$ shows international interest ratios and $\mathrm{x}$ shows the expected loss in value in the exchange ratio.

If the domestic interest rate increases more than the international interest rate, then national currency shall gradually lose value according to foreign exchange rate markets equation. Fleming (1962), Mundell (1963), and Dornbusch (1976) and in both Neo-Keynesian models, if this future value loss is late in price adaptation at the beginning, it requires a valuation on domestic currency. Thus, domestic products become more expensive than international products. Moreover, net export, domestic production and employment decrease.

\subsection{Asset Prices Channel}

Asset price channel is emphasized with q-theory of Tobin (1969) investment and consumption lifecycle theory of Ando and Modigliani (1963). q of Tobin measures market value of the company against the replacement cost of physical capital of the company. While the other conditions are stable, the increases in short-term nominal interest rates make debt instruments more attractive than stock certificates in the eyes of the investments. Therefore, following monetary tightening, the balance between securities markets should be reestablished with the decrease in asset prices. The low Q means the company should issue new stock certificate in order to finance new investment projects. This means the investment shall be more costly for the company.

\subsection{Credit Channel}

Bank credit channel shows the connection between reel industry and financial industry. It establishes the differences made by financial intermediaries during meeting of fund demands. It is important to see how much these credits contributed to the economy and what is the cash flow of these credits following the lend of credit. (Taylor, 2002:23)

Monetary policy decisions affect reel economy through 2 different credit channel, bank credits and balance sheet channel. According to the lending opinion accepted by many economists, banks contribute in the markets only to credit lending, deposit keeping and monetary policy. Moreover, they contribute to the economy of the country with the assets kept. However, a monetary tightening to be applied by CB means a tightening on the deposits to go to the banks directly and therefore a decrease in the bank credits, limitation on the money to be transmitted to the reel economy. This means less production output and more unemployment.

\subsection{Exchange Rate Channel}

Exchange rate channel shows the impulses of changes on monetary policy applied and exchange rate on national revenue and prices in general. Undoubtedly, it is directly related with the internal dynamics of the country, value of the domestic currency against strong currencies how effective exchange rate channel is. The effects of exchange rate channel have 
become stable for all relevant Countries with the Euro Union created by European Union member countries (Boivin, Giannoni, \& Mojon, 2008).

A change in interest rates of the country shall cause different preferences among financial instruments and change the value of the domestic currency. The change in exchange rate means the domestic currency having a changing value against foreign currencies shall be effective on production level and foreign trade of the country. Upon devaluation of the national currency, the prices shall increase and inflation shall occur.

The changes in exchange rates cause product price changes and the product prices vary among markets. It is important to know how long exchange rate channel shall affect the production and prices in general. Therefore, it is obligatory within monetary transmission mechanism to understand exchange rate channel (Smets \& Wouters, 1999).

It is related with the size and openness of the economy to see how quick the monetary policies applied affect exchange rate. In a big economy, monetary transmission mechanism shall not work with exchange rate channel. For example, if tightening monetary policy is followed in one economy, then the domestic currency shall gain value and export shall be expensive. This shall decrease the export. Therefore, exchange rate mechanism shall cause decrease in production and national revenue. On the other hand, the effect of exchange rate channel in big and closed economies such as European Union, the impulse of exchange rate channel shall be lower (European Central Bank, 2000: 44).

\section{Methodology and Data}

In this study in order to investigate the existence of monetary transmission mechanism, annual data (2002-2014) of 15 member countries of European Union has been included in the study. The European Union countries included in the study are Austria, Belgium, Bulgary, Denmark, France, Germany, Greece, Ireland, England, Litvania, Poland, Portugal, Slovakia, Spain, Sweden. Data collected from Eurostat and E-views 7 was used to estimate the models.

Data used in the study:

stockex $i t$; Country share price indices (Name of indices are given in Appendix 1)

int $_{i t}$; Bond yield

credit $_{i t}$; Credit flow

rer $_{i t}$; Real effective exchange rate

ipi $_{i t}$; Industrial production index

Industrial production index wasn't used as a transmission channel in the study but it's used to determine if the production of the countries affected the monetary transmission mechanisms in different channels. The aim was to find out if the industrial production index shocks have a negative effect on the monetary transmission channels.

According to the equation without intercept and trend of unit root tests of Levin, Lin and Chu (LLC), Im, Pesaran and Shin (IPS), Fischer-ADF; the null hypothesis claiming 'int', 'credit' and 'ipi' variables include $1 \%$ unit root is rejected. We found that the series are stable in their level values except 'dstockex'. According to the test equation including intercept, 'rer' variable was found stable for $5 \%$ and $1 \%$ in every three test. It was seen that 'stockex' variable is not stable on level value but got stable on the first difference. 'dstockex' variable 
symbolizes first difference of stock market series. The results are shown in Table 1.

Table 1. Stationary test findings

\begin{tabular}{|c|c|c|c|c|c|c|c|c|c|c|}
\hline & \multicolumn{2}{|c|}{ dstockexchange } & \multicolumn{2}{|c|}{ interest rate } & \multicolumn{2}{|c|}{ credit } & \multicolumn{2}{|c|}{ exchange rate } & \multicolumn{2}{|c|}{$\begin{array}{l}\text { industrial production } \\
\text { index }\end{array}$} \\
\hline & Int. & None & Int. & None & Int. & None & Int. & None & Int. & None \\
\hline \multirow{2}{*}{ Metot } & \multicolumn{2}{|c|}{ Statistics } & \multicolumn{2}{|c|}{ Statistics } & \multicolumn{2}{|c|}{ Statistics } & \multicolumn{2}{|c|}{ Statistics } & \multicolumn{2}{|c|}{ Statistics } \\
\hline & \multicolumn{2}{|c|}{ Prob. } & \multicolumn{2}{|c|}{ Prob. } & \multicolumn{2}{|c|}{ Prob. } & \multicolumn{2}{|c|}{ Prob. } & \multicolumn{2}{|c|}{ Prob. } \\
\hline \multirow{2}{*}{$\begin{array}{c}\text { Levin, Lin } \\
\text { \& Chu }\end{array}$} & -6.91299 & -8.66006 & 0.38783 & -5.67867 & -0.70648 & -3.90652 & -4.40563 & 2.23108 & -8.91141 & -9.06329 \\
\hline & $(0.00 * * *)$ & $(0.00 * * *)$ & $(0.6509)$ & $(0.00 * * *)$ & $(0.2399)$ & $\left(0.00^{* * *}\right)$ & $(0.00 * * *)$ & $(0.9872)$ & $(0.00 * * *)$ & $\left(0.00^{* * *}\right)$ \\
\hline \multirow{2}{*}{$\begin{array}{c}\text { Im, Pesaran } \\
\text { and Shin } \\
\text { W-stat }\end{array}$} & -3.17799 & & 1.27265 & & 0.20991 & & -2.15862 & & -5.84252 & \\
\hline & $(0.0007)$ & & $(0.8984)$ & & $(0.5831)$ & & $(0.0154 * *)$ & & $(0.00 * * *)$ & \\
\hline \multirow{2}{*}{$\begin{array}{c}\text { ADF - } \\
\text { Fisher } \\
\text { Chi-square }\end{array}$} & 50.1887 & 102.861 & 17.2377 & 60.3326 & 23.8406 & 44.4175 & 43.4597 & 8.66967 & 81.6361 & 119.65 \\
\hline & $(0.0062)$ & $(0.00 * * *)$ & $(0.9437)$ & $(0.0004 * * *)$ & (0.6899) & $(0.0253 * *)$ & $(0.0314 * *)$ & $(0.9998)$ & $(0.00 * * *)$ & $(0.00 * * *)$ \\
\hline \multirow{2}{*}{$\begin{array}{l}\text { PP - Fisher } \\
\text { Chi-square }\end{array}$} & 52.6474 & 101.717 & 18.2304 & 65.3552 & 27.0702 & 44.8929 & 43.9477 & 9.46602 & 105.77 & 119.384 \\
\hline & $(0.0032)$ & $\left(0.00^{* * *}\right)$ & $(0.9202)$ & $(0.0001)$ & $(0.5144)$ & 0.0226 & $(0.0281)$ & $0.9996)$ & $\left(0.00^{* * *}\right)$ & $\left(0.00^{* * *}\right)$ \\
\hline
\end{tabular}

Values in parenthesis indicates the probability values relating to the test statistic.According to the significance level; for $10 \% ;(*)$, for $5 \% ;(* *)$ for $1 \%(* * *)$ According to the test statistic indicates that the relevant variables stationary.

\subsection{Granger Causality Test}

"Granger Causality Test" was used in this study to understand the causality relationship among 'dstockex', 'credit', 'int', 'rer' and 'ipi'. Lag lengths in Granger causality analysis have been determined using Akaike information criteria. Lag length criteria are listed in Appendix 3. The series except 'dstockex' (stable first difference) used in causality test are series whose level values are used and stable. 
Table 2. Granger causality findings

\begin{tabular}{|l|l|l|l|}
\hline $\mathbf{H}_{\mathbf{0}}$ Hypothesis & F value & F Prob. & Decision \\
\hline 'Dstockex' doesn't granger cause of 'credit'. & 9.91595 & $0.0001^{*}$ & Causality from 'dstockex' to 'credit'. \\
\hline 'Dstockex' doesn't granger cause of 'credit'. & 12.1432 & $0.000^{*}$ & Causality from 'dstockex' to 'rer'. \\
\hline 'Dstockex' doesn't granger cause of 'ipi'. & 7.65784 & $0.0007^{*}$ & Causality from 'dstockex' to 'ipi'. \\
\hline 'ipi' doesn't granger cause of 'int'. & 3.24543 & $0.0417^{*}$ & Causality from 'ipi' to 'int'. \\
\hline 'Credit' doesn't granger cause of 'ipi'. & 9.95145 & $0.000 *$ & Causality from 'credit' to 'ipi'. \\
\hline 'Ipi'doesn't granger cause of 'rer'. & 3.63867 & $0.0289^{*}$ & Causality from 'ipi' to 'rer'. \\
\hline
\end{tabular}

Based on Granger causality results and theory, the series were added to VAR Analysis model from exterior to interior in order of; 'dstockex', 'credit', 'ipi', 'int' and 'rer'.

\subsection{Variance Decomposition Analysis}

As it is difficult to interpret the coefficients of VAR Models individually, they should be anticipated with variance decomposition methods. Variance Decomposition analysis tables of the study where monetary transmission mechanism channels are analyzed under 4 main titles ('interest rate', 'stock exchange', 'real effective exchange rate' and 'credit') are given in Appendix 1.

It is seen that 'int' of monetary transmission channels responded most certainly against 'credit'. It is seen from the variance decomposition results given in Appendix 4 that this effect raised to $9.009 \%$ in 7 periods. In parallel with the result of Granger causality analysis, it is seen that 'rer' 'is not decisive on 'int'. Moreover, it has been determined that 'ipi's effect on 'int' is limited at $1.5 \%$ according to the variance decomposition results. It is also among the results obtained that the impulse of 'dstockex' on 'interest' is relatively limited.

It is seen in Appendix 5 that 'dstockex' responds most certainly to 'interest' of monetary transmission channels. It is seen from variance decomposition results that this effect raised to $5 \%$ within five periods. It is seen that 'ipi' is the second variable deterministic on 'dstockex'. It is determined that this impulse is relatively low impulse and rose to $2.2 \%$ within ten periods. Lastly, impulses of 'rer' $(0.2 \%$ within ten periods) and 'credit' $(0.9 \%$ within ten periods) on 'dstockex' are quite low.

It is also seen from variance decomposition findings in Appendix 6 that 'dstockex' has the highest effect on 'credit' (17\% in the third period). It is also observed that 'dstockex' as an exterior variable creates a decisive impulse on 'credit'. It is also seen that this effect has continued for ten periods. 'Interest rate' is the channel creating the second highest change on 'credit'. Moreover, it is seen that this effect has been limited at $2 \%$ level. It has been determined that 'rer' has scarcely effect on 'credit'.

The response of 'rer' of monetary transmission channels is more specifically arising from 'ipi' and secondly from 'credit'. As it is seen in Appendix 7 that the change created by 'ipi' on 'rer' reaches to $10 \%$ level within five periods. 'credit's decisive effect on 'rer' is almost as certain as 'ipi'. It is seen that $10 \%$ effect continues without degradation within ten periods. In 
the second and third periods a certain impulses of 'dstockex' is seen on 'rer' around the level $5 \%$. It has been stated that this effect degrades in time. Moreover, it is another remarkable result that 'int' has a quite low effect on 'rer'.

\section{Conclusion}

We try to figure out in the study what the impulse of monetary transmission mechanism shall be in 15 European Union member countries. Yearly data of 2002-2014 has been used in the study, Panel Vector Autoregressive Model has been estimated and results of Variance Decomposition have been interpreted.

In the study stock market indexes representing asset prices as one of the channels of monetary transmission mechanism, bond returns to show interest rate channel, private industry credit flow to show credit channel, real effective exchange rate as exchange rate channel and industrial production index variables to determine the effect of monetary policy decisions on production have been used.

In the study, firstly, stationary of variables have been tested with the panel unit root tests and it has been observed that all variables are stable at level value except the stock exchange market. The stock market variable became stable at the first difference and was included in the study. According to Granger Causality Test findings, the series have been respectively determined as stock market, credit, industry production index, interest rate and exchange rate from exogenous to endogenous before being included into VAR Analysis. According to variance decomposition analysis results of VAR model, it has been determined that among the four main monetary transmission mechanisms, the credit channel has the highest change and this arises from the stock market variable. It is notable that the second highest change is at exchange rate channel and arises from industry production index.

It is among the results obtained that credit channel also has a decisive role on the exchange rate. Relatively strong effect of credit channel is seen on interest rate channel and relatively weak effect of other variables on stock market representing the asset prices are among the notable findings.

When these results are interpreted as a whole, the basic process of monetary transmission mechanism may be summarized as: The stock exchange market representing the asset prices is a result of the change in the other channels and this effect is most highly seen on credit channel. It has been concluded that among the other variables, the interest rate variable effect the stock exchange market. It has been obtained as findings that industry production index creates the highest effect on exchange rate channel and the second variable credit channel creates effect in the long term.

\section{References}

Angeloni I., \&Ehrmann, M. (2003). Monetary Transmission in the Euro Area: Early Evidence, Economic Policy." European Central Bank Working Paper Series, 18(37), 469-501.

Bernanke, B. S., \& Gertler, M. (1995). Inside the Black Box: The Credit Channel of Monetary Policy Transmission. Journal of Economic Perspectives, 9, 27-48. https://doi.org/10.1257/jep.9.4.27

Boivin, J., Giannoni, M. P., \& Mojon, B. (2008). How Has The Euro Changed The Monetary 


\section{Macrothink}

Transmission?” NBER Working Papers, No.14190.

Camarero, M., Ordónez, J., \&Tamarit, C. (2002). Monetary Transmission in Spain: a Structural Cointegrated VAR Approach." Applied Economics, 34(17), 2201-2212. https://doi.org/10.1080/00036840210138419

De Bondt, G. (2002). Retail Bank Interest Rate Pass-Through: New Evidence at the Euro Area Level. ECB Working Paper, 136.

Dornbusch, R. (2002). Exchange Rate and Inflation.MIT Press, Cambridge, MA.

European Central Bank. (2000). Monetary Policy Transmission in the Euro-Area. Monthly Bulletin, July, 43-58.

Gerlach, S., \& Smets, F. (1995). The Monetary Transmission Mechanism: Evidence From the G-7 Countries. Bank for International Settlements, Working Paper No. 26. https://doi.org/10.2139/ssrn.868427

Hicks, J. R. (1937). Mr. Keynes and the "Classics"; A Suggested Interpretation. Econometrica, 5(2), 147-159. https://doi.org/10.2307/1907242

Mishkin, F. (2001). The Transmission Channels and the Role of Asset Prices in Monetary Policy. NBER Working Paper, No.8617.

Peersman, G., \& Smets, F. (2001). The Monetary Transmission Mechanism In The Euro Area: More Evidence From VAR Analysis. European Central Bank Working Paper Series, 91.

Petursson, T. G. (2001). The Transmission Mechanism of Monetary Policy. Monetary Bulletin, 4, 62-77.

Smets, F. R., \& Wouters, R. (1999). The Exchange Rate and the Monetary Transmission Mechanism in Germany. De Economist, 147(4), 489- 521. https://doi.org/10.1023/A:1003803228309

Sims, C. A. (1992). Interpreting the Macroeconomic Time Series Facts: The Effects of Monetary Policy. European Economic Review, 36. https://doi.org/10.1016/0014-2921(92)90041-T

Taylor, J. B. (1995). The Monetary Transmission Mechanism: An Empirical Framework. Journal of Economic Perspectives, 9(4), 11-28. https://doi.org/10.1257/jep.9.4.11

Taylor J. B. (2000). The Monetary Transmission Mechanism and the Evaluation of Monetary Policy Rules. Working Papers Central Bank of Chile, 21-46. 


\section{Macrothink}

\section{Appendix 1 Country Stock Exchange Index}

Austria ASX Index

Belgium BEL20 Index

Bulgary BELSTK Index

Denmark KFX Index

France CAC Index

Germany DAX Index

Greece ASE Index

Ireland ISEQ Index

England FTSEMIB Index

Lithuania RIGSE Index

Poland WIG Index

Portugal PSI20 Index

Slovakia SKSM Index

Spain MADX Index

Sweden SMI Index

\section{Appendix 2 Definition of Data}

Interest Rates: Maastricht criterion bond yields (mcby)

Asset Prices: Share price indices

Exchange Rate: Real effective exchange rate of industrial countries (deflator consumer price index)

Credit: Private credit flow in \% of GDP

Industrial Production Index:Production in industry - annual data, percentage change

\section{Appendix 3 VAR Lag Length Criteria}

VAR Lag Order Selection Criteria

Endogenous variables: STOCKEX1 CREDIT INT RER IPI

Exogenous variables: $\mathrm{C}$

Date: 07/23/15 Time: 02:05

Sample: 20022014

Included observations: 31

\begin{tabular}{lllllll}
\hline Lag & LogL & LR & FPE & AIC & SC & HQ \\
\hline 0 & -332.2652 & NA & 1938.704 & 21.75905 & 21.99034 & 21.83444 \\
1 & -238.7758 & 150.7894 & 23.94395 & 17.34037 & 18.72810 & 17.79274
\end{tabular}




$2 \quad-191.8496 \quad 60.54997 * 6.670493 * 15.92578 * 18.46995 * 16.75512 *$

* indicates lag order selected by the criterion

LR: sequential modified LR test statistic (each test at 5\% level)

FPE: Final prediction error

AIC: Akaike information criterion

SC: Schwarz information criterion

HQ: Hannan-Quinn information criterion

Appendix 4 Variance Decomposition of Interest Rate

\begin{tabular}{lllllll}
\hline Period & S.E. & STOCKEX1 & CREDIT & IRI & INT & RER \\
\hline 1 & 3350.884 & 0.004704 & 1.603781 & 0.434043 & 97.95747 & 0.000000 \\
2 & 3462.999 & 0.014107 & 1.343289 & 0.636732 & 97.25530 & 0.750575 \\
3 & 3717.240 & 0.314190 & 1.194711 & 1.232018 & 95.76594 & 1.493140 \\
4 & 3836.259 & 0.366440 & 2.234825 & 1.646757 & 93.92820 & 1.823776 \\
5 & 3873.353 & 0.513515 & 5.011303 & 1.621233 & 91.01599 & 1.837960 \\
6 & 3888.306 & 1.008238 & 7.571958 & 1.570033 & 88.06928 & 1.780491 \\
7 & 3890.820 & 1.396776 & 9.009377 & 1.555471 & 86.29876 & 1.739614 \\
8 & 3893.809 & 1.485748 & 9.592092 & 1.583176 & 85.61570 & 1.723287 \\
9 & 3895.246 & 1.491378 & 9.745518 & 1.619999 & 85.42411 & 1.718998 \\
10 & 3896.416 & 1.491709 & 9.762206 & 1.637814 & 85.38770 & 1.720571 \\
\hline
\end{tabular}

Cholesky Ordering: STOCKEX1 CREDIT IRI INT RER

\section{Appendix 5 Variance Decomposition of Stock Exchange}

\begin{tabular}{lllllll}
\hline Period & S.E. & STOCKEX1 & CREDIT & IRI & INT & RER \\
\hline 1 & 3350.884 & 100.0000 & 0.000000 & 0.000000 & 0.000000 & 0.000000 \\
2 & 3462.999 & 98.04088 & 0.002598 & 0.048622 & 1.725967 & 0.181933 \\
3 & 3717.240 & 96.47867 & 0.010853 & 1.432537 & 1.918145 & 0.159798 \\
4 & 3836.259 & 93.19245 & 0.277888 & 1.913922 & 4.460710 & 0.155028 \\
5 & 3873.353 & 92.00031 & 0.757478 & 2.025097 & 5.022363 & 0.194752 \\
6 & 3888.306 & 91.63846 & 0.833306 & 2.269628 & 4.986863 & 0.271745 \\
7 & 3890.820 & 91.57693 & 0.862954 & 2.267486 & 5.000958 & 0.291676 \\
\hline
\end{tabular}




\begin{tabular}{lllllll}
\hline 8 & 3893.809 & 91.47436 & 0.946348 & 2.292851 & 4.993344 & 0.293100 \\
9 & 3895.246 & 91.43498 & 0.984605 & 2.295459 & 4.989778 & 0.295178 \\
10 & 3896.416 & 91.41462 & 0.998126 & 2.294098 & 4.993176 & 0.299977 \\
\hline
\end{tabular}

Cholesky Ordering: STOCKEX1 CREDIT IRI INT RER

\begin{tabular}{lllllll}
\multicolumn{6}{l}{ Appendix 6 Variance Decomposition of Credit } \\
\hline Period & S.E. & STOCKEX1 & CREDIT & IRI & INT & RER \\
\hline 1 & 3350.884 & 3.235658 & 96.76434 & 0.000000 & 0.000000 & 0.000000 \\
2 & 3462.999 & 15.41293 & 83.60346 & 0.359777 & 0.368501 & 0.255331 \\
3 & 3717.240 & 17.75293 & 79.83642 & 0.341616 & 1.680284 & 0.388754 \\
4 & 3836.259 & 17.00350 & 79.78540 & 0.497022 & 2.136313 & 0.577764 \\
5 & 3873.353 & 16.81811 & 79.65499 & 0.653797 & 2.121605 & 0.751499 \\
6 & 3888.306 & 16.80308 & 79.56436 & 0.659668 & 2.130633 & 0.842255 \\
7 & 3890.820 & 16.79959 & 79.50916 & 0.675140 & 2.132956 & 0.883154 \\
8 & 3893.809 & 16.79045 & 79.47096 & 0.691054 & 2.132830 & 0.914714 \\
9 & 3895.246 & 16.79311 & 79.42386 & 0.699292 & 2.134078 & 0.949657 \\
10 & 3896.416 & 16.78464 & 79.38479 & 0.709704 & 2.133984 & 0.986883 \\
\hline
\end{tabular}

Cholesky Ordering: STOCKEX1 CREDIT IRI INT RER

Appendix 7 Variance Decomposition of Reel Effective Exchange Rate

\begin{tabular}{lllllll}
\hline Period & S.E. & STOCKEX1 & CREDIT & IPI & INT & RER \\
\hline 1 & 3350.884 & 0.291779 & 0.784118 & 0.859071 & 1.628902 & 96.43613 \\
2 & 3462.999 & 5.282272 & 0.343877 & 1.986508 & 0.872935 & 91.51441 \\
3 & 3717.240 & 4.279637 & 2.409343 & 5.179708 & 0.576183 & 87.55513 \\
4 & 3836.259 & 3.093000 & 5.218118 & 8.621642 & 0.407228 & 82.66001 \\
5 & 3873.353 & 2.584530 & 7.059684 & 10.75970 & 0.356193 & 79.23989 \\
6 & 3888.306 & 2.542166 & 8.066929 & 11.72790 & 0.321059 & 77.34194 \\
7 & 3890.820 & 2.465244 & 8.727049 & 12.32137 & 0.288130 & 76.19821 \\
8 & 3893.809 & 2.313001 & 9.238353 & 12.84916 & 0.271175 & 75.32831 \\
9 & 3895.246 & 2.196242 & 9.632730 & 13.27251 & 0.266665 & 74.63185 \\
10 & 3896.416 & 2.133631 & 9.939201 & 13.56803 & 0.262638 & 74.09650 \\
\hline
\end{tabular}

Cholesky Ordering: STOCKEX1 CREDIT IPI INT RER 
Appendix 8 VAR Model Vector Autoregression Estimates

Date: 10/22/15 Time: 19:11

Sample (adjusted): 20052014

Included observations: 128 after adjustments

Standard errors in ( ) \& t-statistics in [ ]

\begin{tabular}{|c|c|c|c|c|c|}
\hline & STOCKEX1 & CREDIT & IPI & INT & RER \\
\hline \multirow[t]{3}{*}{ STOCKEX1(-1) } & 0.228670 & 0.000709 & 0.000476 & $-8.96 \mathrm{E}-06$ & 0.000296 \\
\hline & $(0.08971)$ & $(0.00018)$ & $(0.00016)$ & $(4.9 \mathrm{E}-05)$ & $(7.9 \mathrm{E}-05)$ \\
\hline & {$[2.54906]$} & [ 3.97933] & {$[3.00372]$} & {$[-0.18106]$} & [ 3.76844] \\
\hline \multirow[t]{3}{*}{ STOCKEX1(-2) } & -0.456532 & -0.000198 & -0.000390 & $1.77 \mathrm{E}-05$ & -0.000354 \\
\hline & $(0.09450)$ & $(0.00019)$ & $(0.00017)$ & $(5.2 \mathrm{E}-05)$ & $(8.3 \mathrm{E}-05)$ \\
\hline & {$[-4.83123]$} & {$[-1.05628]$} & {$[-2.33755]$} & {$[0.33868]$} & {$[-4.27879]$} \\
\hline \multirow[t]{3}{*}{ CREDIT(-1) } & -2.794628 & 0.778407 & -0.021345 & -0.012794 & -0.022713 \\
\hline & $(52.2049)$ & $(0.10368)$ & $(0.09215)$ & $(0.02880)$ & $(0.04570)$ \\
\hline & {$[-0.05353]$} & {$[7.50790]$} & {$[-0.23162]$} & {$[-0.44423]$} & {$[-0.49698]$} \\
\hline \multirow[t]{3}{*}{ CREDIT(-2) } & -34.85062 & -0.088737 & -0.106791 & 0.050450 & 0.101010 \\
\hline & $(51.3984)$ & $(0.10208)$ & $(0.09073)$ & $(0.02836)$ & $(0.04500)$ \\
\hline & {$[-0.67805]$} & {$[-0.86932]$} & {$[-1.17701]$} & [ 1.77922$]$ & [2.24488] \\
\hline \multirow[t]{3}{*}{ IPI(-1) } & -18.20690 & 0.093080 & 0.049863 & 0.054749 & 0.163348 \\
\hline & $(58.3439)$ & $(0.11587)$ & $(0.10299)$ & $(0.03219)$ & $(0.05108)$ \\
\hline & {$[-0.31206]$} & {$[0.80332]$} & {$[0.48414]$} & [ 1.70099$]$ & [ 3.19812] \\
\hline \multirow[t]{3}{*}{ IPI(-2) } & 98.89545 & $5.61 \mathrm{E}-05$ & 0.093051 & -0.088865 & 0.098052 \\
\hline & $(50.8507)$ & (0.10099) & $(0.08976)$ & $(0.02805)$ & $(0.04452)$ \\
\hline & [ 1.94482$]$ & {$[0.00056]$} & [ 1.03661$]$ & {$[-3.16775]$} & [ 2.20259] \\
\hline \multirow[t]{2}{*}{ INT(-1) } & -259.1529 & -0.275472 & -0.607295 & 0.872485 & -0.124067 \\
\hline & (180.704) & $(0.35888)$ & $(0.31899)$ & $(0.09969)$ & $(0.15819)$ \\
\hline
\end{tabular}


$[-1.43413]$

$[-0.76760] \quad[-1.90382] \quad[8.75201][-0.78427]$

$\operatorname{INT}(-2)$

412.7536

0.039861

0.506680

$-0.294428$

0.127749

(247.982)

(0.49249)

$(0.43775)$

(0.13681) (0.21709)

[1.66445]

[0.08094]

[ 1.15746$]$

[-2.15216] [0.58845]

$\operatorname{RER}(-1)$

51.27489

$-0.163302$

0.030919

$0.074610 \quad 1.083589$

(93.4552)

(0.18560)

(0.16497)

(0.05156) (0.08181)

[0.54866]

[-0.87986]

[0.18742]

[ 1.44713] [ 13.2446]

RER(-2)

$-53.46947$

0.131501

0.056396

$-0.065975-0.093134$

(100.015)

(0.19863)

(0.17655)

(0.05518) (0.08756)

$[-0.53461]$

[0.66204] [0.31943]

[-1.19573] [-1.06370]

C

$-72.45965$

5.886050

$-6.735336$

$0.616729 \quad 0.470919$

(3810.53)

(7.56767)

(6.72654)

(2.10217) (3.33587)

-

R-squared

[-0.01902]

$[0.77779] \quad[-1.00131] \quad[0.29338][0.14117]$

Adj. R-squared

0.235981

0.626212

0.203305

0.539942

0.912938

Sum sq. resids

0.170680

0.594264

0.135211

0.500621

0.905496

S.E. equation

$1.31 \mathrm{E}+09$

5181.537

4093.714

$399.8266 \quad 1006.820$

F-statistic

3350.884

6.654821

5.915151

$\begin{array}{ll}1.848600 & 2.933479\end{array}$

Log likelihood

3.613748

19.60116

2.985668

13.73160

122.6863

Akaike AIC

$-1214.847$

$-418.4770$

$-403.3955$

$-254.5202-313.6255$

19.15385

6.710579

6.474930

$4.148753 \quad 5.072274$

Schwarz SC

19.39895

6.955675

6.720026

$4.393849 \quad 5.317370$

Mean dependent

193.3675

7.364063

0.800781

$4.561641 \quad 103.9438$

S.D. dependent

3679.581

10.44756

6.360787

$2.615940 \quad 9.542419$

Determinant resid covariance (dof adj.)

$3.56 \mathrm{E}+11$

Determinant resid covariance

$2.27 \mathrm{E}+11$

Log likelihood

$-2581.680$

Akaike information criterion

41.19813

Schwarz criterion

42.42361 


\section{Macrothink}

Journal of Social Science Studies

ISSN 2329-9150

2017, Vol. 4, No. 2

\section{Copyright Disclaimer}

Copyright for this article is retained by the author(s), with first publication rights granted to the journal.

This is an open-access article distributed under the terms and conditions of the Creative Commons Attribution license (http://creativecommons.org/licenses/by/3.0/). 